\title{
Role of type 1 natural killer T cells in pulmonary immunity
}

\author{
C Paget Pa,2,4,5,6,7 and F Trottein $^{3,4,5,6,7}$
}

Mucosal sites are populated by a multitude of innate lymphoid cells and "innate-like" $\mathrm{T}$ lymphocytes expressing semiconserved T-cell receptors. Among the latter group, interest in type I natural killer T (NKT) cells has gained considerable momentum over the last decade. Exposure to NKT cell antigens is likely to occur continuously at mucosal sites. For this reason, and as they rapidly respond to stress-induced environmental cytokines, NKT cells are important contributors to immune and inflammatory responses. Here, we review the dual role of mucosal NKT cells during immune responses and pathologies with a particular focus on the lungs. Their role during pulmonary acute and chronic inflammation and respiratory infections is outlined. Whether NKT cells might provide a future attractive therapeutic target for treating human respiratory diseases is discussed.

\section{INTRODUCTION}

Mucosae are continuously exposed to self and environmental triggers and serve as a first line of defense against various pathogens and insults. Establishment of immune responses at these sites needs to be tightly regulated in order to contain and/or eliminate pathogens, to generate effective memory against them, and to prevent the development of uncontrolled inflammation and/or autoimmune diseases. Considering this, the nature and distribution of immune cells in mucosal tissues are of upmost importance. Among "innatelike" $\mathrm{T}$ lymphocytes that populate these sites are mucosalassociated invariant $\mathrm{T}$ cells, $\gamma \delta \mathrm{T}$ lymphocytes and natural killer $\mathrm{T}$ (NKT) cells expressing a semiconserved T-cell receptor (TCR).

NKT cells are a unique subset of thymus-derived T cells that carry a functional antigen $(\mathrm{Ag})$ receptor but also display similarities with innate immune cells through their rapid activation in response to multiple lipid Ags and/or cytokines. Despite their relative low numbers at mucosal sites, NKT cells act as sentinels during infections to elicit early host defense mechanisms and sometimes can be involved in the pathogenesis in a variety of diseases. In this review, we will focus on current understanding and gaps in knowledge regarding NKT cell functions in pulmonary immunity.
Definition, development, and homeostasis

NKT cells represent a population of innate/memory unconventional $\mathrm{T}$ lymphocytes that co-express markers typically found on NK cells and conventional T lymphocytes. Unlike conventional T lymphocytes, which recognize peptide Ags, NKT cells recognize a broad range of endogenous and exogenous lipid Ags presented by the monomorphic major histocompatibility complex class 1-like CD1d molecule. CD1drestricted NKT cells are divided into two major subsets (Table 1) based on their TCR repertoire and antigenicity profile. ${ }^{1-3}$ By far, the best-characterized NKT cell subset is the "type 1 NKT cell" population. They express an invariant TCR- $\alpha$ chain (V $\alpha 14-J \alpha 18$ in mice and $V \alpha 24-J \alpha 18$ in humans) paired with a limited number of $\beta$-chains $(\mathrm{V} \beta 8.2, \mathrm{~V} \beta 7$, or $\mathrm{V} \beta 2$ in mice and $V \beta 11$ in humans). An important feature of type 1 NKT cells is that, after endogenous or exogenous TCR-mediated activation, they promptly produce a wide array of cytokines and chemokines. ${ }^{4}$ Through this property, type 1 NKT cells are viewed as important cells to conduct early effector and regulatory functions.

The second major subset of NKT cells is termed type 2 NKT cells. These cells have a more diverse TCR repertoire and recognize an almost completely different pattern of CD1dassociated ligands compared with type 1 NKT cells. ${ }^{5,6}$ Although

\footnotetext{
${ }^{1}$ Cancer Immunology Program, Peter MacCallum Cancer Centre, St. Andrews Place, East Melbourne, Victoria, Australia. ${ }^{2}$ Sir Peter MacCallum Department of Oncology and Department of Pathology, University of Melbourne, Parkville, Victoria, Australia. ${ }^{3}$ Institut Pasteur de Lille, Centre d'Infection et d'Immunité de Lille, Lille, France. ${ }^{4}$ Institut National de la Santé et de la Recherche Médicale, Lille, France. ${ }^{5}$ Centre National de la Recherche Scientifique, UMR 8204 , Lille, France. ${ }^{6}$ Université Lille Nord de France, Lille, France and ${ }^{7}$ Institut Fédératif de Recherche 142, Lille, France. Correspondence: C Paget (christophe.paget@pasteur-lille.fr) or F Trottein (francois.trottein@pasteur-lille.fr) 
Table 1 Major populations of CD1d-restricted NKT cells

\begin{tabular}{|c|c|c|}
\hline NKT cell family & Type 1 NKT cells & Type 2 NKT cells \\
\hline TCR- $\alpha$ chain & $\begin{array}{l}\vee \alpha 14 J \alpha 18(M) \\
V \alpha 24 J \alpha 18(H)\end{array}$ & $\begin{array}{c}\text { Diverse, including } V_{\alpha} 3.2, \\
\qquad \alpha 8(\mathrm{M}) \text { and some } \\
\gamma \delta T \text { cells }\end{array}$ \\
\hline TCR- $\beta$ chain & V $\beta 7.2, \quad V \beta 8.2(M) \vee \beta 11(H)$ & Diverse including $\vee \beta 8.2$ \\
\hline $\begin{array}{l}\text { Markers defining } \\
\text { subsets }\end{array}$ & $\begin{array}{c}\text { CD4, NK1.1 (M) CD4, } \\
\text { CD8 }(\mathrm{H})\end{array}$ & CD4 \\
\hline $\begin{array}{l}\alpha \text {-GalCer } \\
\text { reactivity }\end{array}$ & Yes & No \\
\hline Other Ags & $\begin{array}{c}\text { iGb3, } \alpha \text {-GlcCer, } \beta \text {-GlcCer, } \\
\beta \text {-GalCer, } \alpha \text {-GalDAG, } \\
\alpha \text {-GlcDAG, } \beta \text {-ManCer }\end{array}$ & $\begin{array}{c}\text { Sulphatide, Cardiolipin, } \\
\beta \text {-GlcCer, } \beta \text {-GalCer }\end{array}$ \\
\hline
\end{tabular}

Abbreviations: Ags, antigens; $\alpha$-GalCer, $\alpha$-galactosylceramide; NKT, natural killer T cell; TCR, T-cell receptor.

recent progresses have been made concerning the functions and characterization of these cells, the lack of specific molecular markers preclude any thorough investigation at the moment. Nevertheless, this population has been associated with strong immunomodulatory properties in many settings including autoimmunity, infections, and cancer. ${ }^{5,7}$ More recently, an atypical population of NKT cells (termed type 1a NKT cells) that does not fit perfectly in the type 1/type 2 classification has been described. ${ }^{8}$ These cells express a semi-invariant V $\alpha 10 \mathrm{~J} \alpha 50$ TCR and, similarly to type 1 NKT cells, they recognize $\alpha$-galactosylceramide $(\alpha$-GalCer) in a CD1d-dependent manner. However, the functions of this subset remain to be determined. In this review, we will focus our interest on type 1 NKT cells (referred here as NKT cells).

NKT cells originate from the thymus where they are selected by endogenous lipids presented by the CD1d molecules expressed by double-positive thymocytes. ${ }^{9}$ After several rounds of cell division, NKT cells acquire a memory/effector phenotype before thymic emigration. Recent data demonstrated that NKT cells require post-thymic education by commensal microbiota to fully mature and to acquire their functionality. ${ }^{10,11}$ NKT cells are found in various peripheral organs including the liver ( $\sim 30 \%$ of $\mathrm{T}$ cells in mice, $\sim 1 \%$ in human), spleen (10-fold less), lymph nodes ( 0.1-0.5\% of lymphocytes), and bloodstream ( $\sim 0.2 \%$ of circulating cells). They are far more abundant in mice than in humans, a likely consequence of the lack/low frequency of CD1a/b/c-restricted T cells and mucosalassociated invariant $\mathrm{T}$ cells in mice. For still undetermined reasons, there is a high frequency of NKT cells in the omentum in humans $(\sim 10 \%$ of $\mathrm{T}$ cells $) .{ }^{12}$ Mucosae are also populated with NKT cells as they have been described in lungs, intestine, and reproductive tracts. At steady state, mouse NKT cells represent $\sim 5-10 \%$ of the T-cell pool in the lungs where they constitutively reside in the microvasculature with a broad distribution in peribronchiolar and interalveolar capillaries. ${ }^{13}$ Information from human studies is less compelling, although NKT cells have been detected in BAL $^{14}$ and sputum ${ }^{15}$ at very low frequencies $(0.1-0.2 \%$ of $\mathrm{T}$ cells).

\section{Functions and classification}

NKT cells recognize exogenous and endogenous (glyco)lipids presented by the CD1d molecule expressed by Ag-presenting cells, including dendritic cells (DCs). The prototypic NKT cell activator in mice and humans is $\alpha$-GalCer, an $\alpha$-linked glycosphingolipid originally isolated from a marine sponge. ${ }^{16}$ In parallel, NKT cells can be activated by microbial lipids and, to a lesser extent, by stress-induced self-lipids. In response to TCR engagement, NKT cells promptly release a wide array of cytokines including interferon (IFN)- $\gamma$, interleukin (IL)-4, and/or IL-17 and upregulate several co-stimulatory molecules. These events contribute to the reciprocal maturation of surrounding Ag-presenting cells, for instance, the release of activating cytokines (e.g., IL-12 and IL-18), and ending up with the downstream activation of NK cells, neutrophils, macrophages, $\gamma \delta \mathrm{T}$ cells and $\mathrm{B}$ and $\mathrm{T}$ lymphocytes with important outcomes on the immune response. ${ }^{17-22}$ NKT cells also exert cytolytic activity through granzyme $\mathrm{B}$ secretion and FAS ligand-induced apoptosis mechanism. ${ }^{23}$ According to the nature of cytokines produced, NKT cells differently influence the character and the strength of innate and acquired immune responses. Of importance, NKT cells also have a part in tolerance induction, thus highlighting their functional plasticity. ${ }^{24-27}$ Through these unique properties, NKT cells influence host defense responses and pathologies including autoimmune diseases, inflammation, resistance to tumors, and antimicrobial responses with either protective (tumor resistance, infections) or deleterious (inflammatory diseases) effects. $^{1,3,28}$

NKT cells promote/orientate or suppress immune responses, presumably owing to the existence of distinct subsets with specialized functions. ${ }^{1,3,9}$ Several distinct populations of NKT cells, based on CD4, NK1.1, and IL-25 receptor (IL-17RB) expression have been reported and differ in their cytokine profile and functions (Figure 1). The $\mathrm{CD} 4{ }^{-}$subset is associated with a more pronounced ability in producing $\mathrm{T}$ helper $1(\mathrm{Th} 1)$ related cytokines and is proposed to bear a marked antitumor activity relative to their $\mathrm{CD} 4{ }^{+}$counterparts. ${ }^{29,30}$ Although $\mathrm{CD} 4{ }^{+}$NKT cells produce both Th1- and T helper 2 (Th2)related cytokines, ${ }^{30}$ expression of IL-17RB defines cells with a higher capacity to secrete IL-13 and IL- 4 but little IFN- $\gamma$, an important property in Th2-mediated diseases. ${ }^{31,32}$ Finally, the NK1.1 $1^{-} \mathrm{CD} 4^{-}$NKT subset expressing the retinoic acid receptor-related orphan receptor- $\gamma \mathrm{t}$ produces high amounts of IL-17A ${ }^{33,34}$ and IL-22. ${ }^{35-37}$ Unlike the mouse system, human develops a $\mathrm{CD}^{+}{ }^{+} \mathrm{NKT}$ subset, although its functional impact has to be defined.

NKT cell subtypes have a preferential distribution pattern that fits nicely with their putative functions. For example, NK1.1 ${ }^{-}$retinoic acid receptor-related orphan receptor- $\gamma \mathrm{t}^{+}$ NKT cells (a subset that co-expresses CCR6) are enriched in skin and peripheral lymph nodes and to a lesser extent in the lungs. ${ }^{34,35}$ Regarding the critical role for IL-17 in mucosal immunity ${ }^{38}$ this pattern of distribution is not surprising. NKT cell diversity and localization can partially explain the pleiotropic, but not redundant, functions of these cells, 


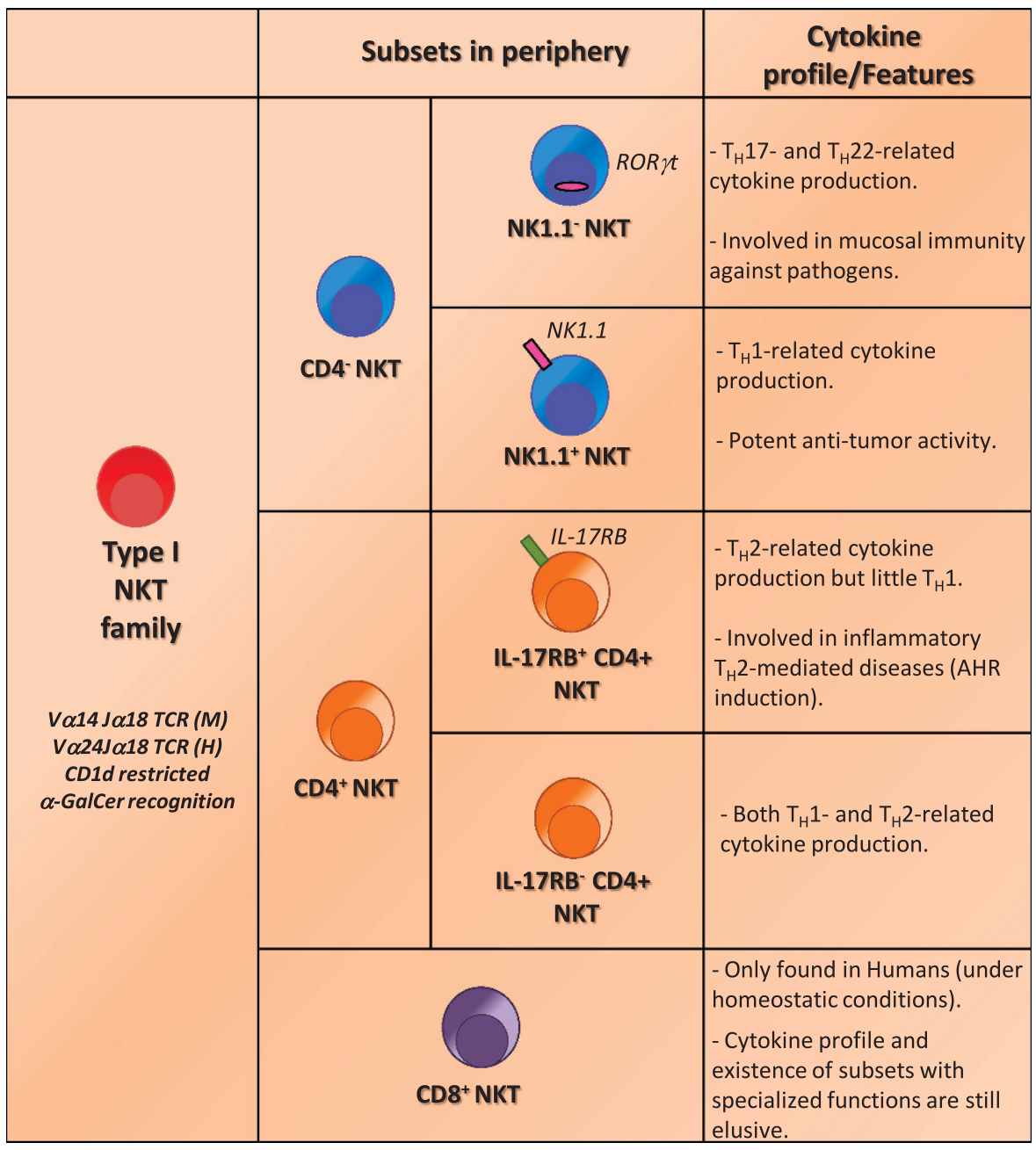

Figure 1 Subsets of peripheral type 1 natural killer T (NKT) cells and associated functions.

although other factors are likely to be required. Among them, the nature of Ags recognized by NKT cells as well as the microenvironment in which NKT cells primarily become activated are critical.

\section{Role of NKT cells in humans}

NKT cells are less frequent in humans compared with the mouse system, and their proportion in blood, and possibly within organs, greatly vary according to the donor. Although it is well admitted that NKT cells mediate both beneficial and detrimental outcomes in the mouse system, it is also recognized that intrinsic NKT cell defect (deficiency or impaired cytokine production) is associated with human diseases such as multiple sclerosis, graft-vs.-host disease, rheumatoid arthritis, systemic lupus and type 1 diabetes. ${ }^{39,40} \mathrm{~A}$ defect in NKT cells has also been widely described in solid tumors and hematological malignancies and might predispose to infectious diseases such as acute tuberculosis and Epstein-Barr virus. ${ }^{39,41}$ On the other hand, there are situations where NKT cells seem to be pathogenic such as atherosclerosis, allergy, and skin disorders. ${ }^{1,42}$ Clinical trials have been conducted to harness NKT cell functions for therapeutic purposes, particularly in cancer patients. ${ }^{43,44}$ Although $\alpha$-GalCer administration leads to a significant immunological response and is rather well tolerated, the clinical benefits are still limited. Therefore, future progresses are clearly required to increase the efficacy of NKT cell-based therapies. ${ }^{44-46}$ Aside of this, there is an increasing interest in order to manipulate NKT cells to improve vaccine efficacy and to treat autoimmune and inflammatory diseases. ${ }^{47,48}$

\section{Mechanisms of NKT cell activation}

During stressful conditions, including cell transformation, injury, inflammation, and infection, NKT cells rapidly become activated to exert their effector/regulatory functions. The mode of NKT cell activation has been principally studied during infection. NKT cells can respond to diverse microbial pathogens ranging from viruses to helminthic parasites. ${ }^{28,49,50}$ The pattern of Ags recognized by NKT cells is indeed larger than initially believed, as the TCR is likely to act more as a pattern recognition receptor. ${ }^{51}$ Indeed, NKT cells can be activated by various naturally occurring microbial (mostly 
bacterial) lipids presented by CD1d. ${ }^{52-56}$ For instance, the Gram-negative, lipopolysaccharide-lacking, bacteria Sphingomonas, express NKT cell Ags including $\alpha$-glucuronosylceramide and $\alpha$-galacturonosylceramide. ${ }^{52,54-56}$ In addition, other glycolipids and glycerophospholipids from Borrelia burgdorferi, Mycobacterium bovis Bacillus Calmette-Guerin, and Streptococcus pneumoniae can also directly activate NKT cells without any other factors. ${ }^{52,53,57}$ NKT cells also have the ability to respond to innate or inflammatory stimuli in conjunction, or not, with self or microbial Ag. ${ }^{55,58-63}$ In fact, the innatecytokine driven activation seems to be the dominant pathway for NKT cell activation in response to virtually all infectious agents, especially viruses that do not produce lipids. ${ }^{60}$ Innate sensors, including toll-like receptors (TLRs), have a crucial role in the activation of sentinel cells and in the subsequent stimulation of NKT cells. ${ }^{37,55,59,62-64}$ For instance, triggering of TLR4, TLR7, or TLR9 in DCs leads to NKT cell activation. ${ }^{59,62,63}$ In this setting, IL-12, and other cytokines such as IL-18 or IFN type 1 stimulate NKT cells to produce IFN- $\gamma$, in concert or not with self-lipids. Other innate sensors involved in the recognition of microbe-conserved components, including retinoic acid-inducible gene-like helicases and NOD-like receptors might also contribute in the indirect activation of NKT cells, although this has been poorly investigated so far. ${ }^{37}$ The precise identity of self-lipids recognized by NKT cells remains unclear, but $\beta$-linked glycosphingolipids are good candidates. ${ }^{5,61-63,65}$ Among them, $\beta$-D-glucopyranosylceramide, isoglobotrihexosylceramide, and diasialoganglioside might serve as self Ags in some circumstances. ${ }^{55,65-67}$ In parallel, self-phospholipid Ags such as (lyso)phosphatidylethanolamine, phosphatidylinositol, and phosphatidylcholine ${ }^{68-70}$ might have physiological functions.

Various types of soluble stimuli can activate NKT cells to produce IFN- $\gamma$ in the body but far less studies show that NKT cells produce IL-4 or IL-17 during infection. This situation is likely to occur in vivo, depending on the nature of the threat and the organ of interest, yet the mechanisms by which they do so are poorly defined. Similarly, the regulatory role of NKT cells in tolerance and immune suppression presumably requires some forms of activation, which remains to be determined.

\section{NKT CELLS IN INTESTINAL AND URINARY/REPRODUCTIVE TRACT IMMUNITY}

NKT cells populate the digestive tract and have been detected in the lamina propria ( $\sim 1 \%$ of total lymphocytes) and to a lesser extent, in the intraepithelial lymphocyte compartment of both small and large intestine. ${ }^{10,11,71}$ Of note, numerous immune cells in the intestinal tissue display NKT cell phenotypic hallmarks that render mandatory the use of CD1d/ $\alpha$-GalCer tetramers for a meaningful analysis. ${ }^{72-75}$ Consistent with their regulatory functions, intestinal NKT cells have been evoked in the participation of oral tolerance by inducing tolerogenic DCs and by positively influencing the development of regulatory T cells. ${ }^{76}$ On the other hand, mouse NKT cells seem to be implicated in peanut allergen-induced eosinophilic esophagitis. ${ }^{77}$ Moreover, the presence of Th2-biased NKT cells and the high level of CD1d expression in the duodenum of patients with cow's milk hypersensitivity suggested a potential participation of NKT cells in the pathogenesis of food allergy in humans. ${ }^{78,79}$ NKT cells also have a significant role in the development of gut inflammation. Their beneficial vs. pathogenic role in experimental inflammatory bowel diseases is dependent on the model used. In this context, it appears that NKT cells are generally protective during Th1-mediated pathologies (Crohn diseaselike models) and harmful during Th2-mediated diseases (ulcerative colitis models). ${ }^{80,81}$ Surprisingly, relatively few studies have analyzed the role of NKT cells during oral infections. Despite clear signs of activation in response to various intestinal pathogens including the bacterium Listeria and the protozoan parasite Toxoplasma, their natural contribution to the control of intestinal infections is not obvious and controversial. ${ }^{71,82-86}$

Less information is available about the role of NKT cells in immunity of the reproductive tract. However, early IFN $-\gamma$ production by NKT cells contributes to the innate protection against genital herpes simplex virus type 2 infection leading to an enhanced survival and a reduced viral burden. ${ }^{87}$ NKT cells are also locally activated following genital tract Chlamydia infection and participate to the bacterial clearance. ${ }^{88}$ However, by eliciting this inflammatory response, NKT cells have a dual role in the pathology by influencing the development of fibrosis. ${ }^{88}$ Finally, exogenous activation of NKT by means of $\alpha$-GalCer induces a protective role against genital tract Chlamydia muridarum infection. ${ }^{89}$

\section{NKT CELLS IN PULMONARY INFLAMMATION AND LUNG DYSFUNCTION}

NKT cells have been shown to be required for pulmonary disorder in many experimental systems. The mechanisms involved vary according to the model used and the nature of the initial trigger. Here, we will review the role of NKT cells in acute lung injury and fibrosis and on asthma and chronic obstructive pulmonary disease (COPD; Table 2), two major chronic pathologies responsible for high levels of mortality and/or morbidity worldwide and for which there is an increase need for the development of new therapies.

\section{Hypersensitivity reactions and asthma}

Asthma is a common disabling inflammatory respiratory disease that affects millions of people worldwide. ${ }^{90}$ This is a complex disease with several distinct forms that might be associated with several different pathogenic mechanisms. Allergic asthma is the most common form of the disease. Its development occurs against environmental allergens and is characterized by a Th2-polarized immune response, eosinophil infiltrates, high levels of specific IgE, mucus hypersecretion, and airway hyperreactivity (AHR), a cardinal feature of asthma. Non-allergic asthma has common pathological features with allergic asthma, including AHR. Recent advances led to the discovery that environmental factors, including viruses and air pollution, and Th2-independent components, such as neutrophils, IFN- $\gamma$, and IL-17, contribute to the pathogenesis of 
Table 2 Role of type 1 NKT cells in pulmonary inflammation and lung dysfunction

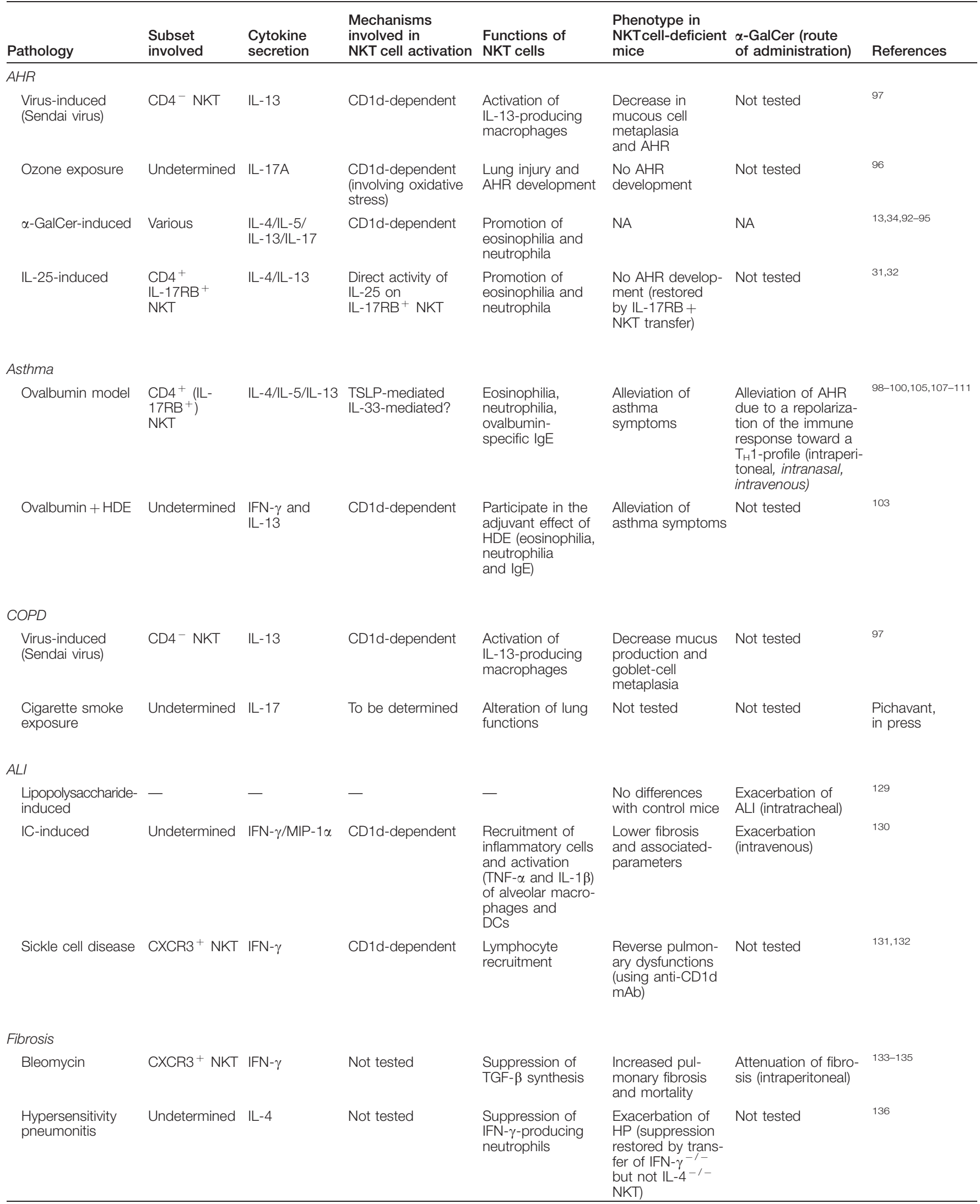

Abbreviations: $\alpha$-GalCer, $\alpha$-galactosylceramide; AHR, airway hyperreactivity; ALI, acute lung injury; COPD, chronic obstructive pulmonary disease; DCs, dendritic cells; HDE, house dust extract; HP, hypersensitivity pneumonitis; IC, immune complex; IFN, interferon; IL, interleukin; NA, not applicable. 
non-allergic asthma. ${ }^{90,91}$ Moreover, it is now well admitted that innate immunity has an important role in asthma development. ${ }^{90,91}$

Airway diseases that resemble asthma can be artificially induced by intranasal administration of $\alpha$-GalCer or microbialderived (i.e., Sphingomonas) NKT cell activators in mice, pigs, and nonhuman primates. ${ }^{13,92-95}$ The pathology has features that resemble farmer's or bird fancier's lung disease and is due to exposure to organic dusts. ${ }^{13}$ Although the production of IL-4/IL-13 is important in AHR development, administration of $\alpha$-GalCer also induces IL-17 production by lung CD4 ${ }^{-}$ NK1.1 ${ }^{-}$NKT cells, which exacerbates neutrophilia and AHR. ${ }^{34}$ Exposure to oxidant pollutants such as ozone also promotes airway neutrophilia and AHR upon a phenomenon that depends on IL-17 production by NK1.1 ${ }^{-}$NKT cells. ${ }^{96}$ Finally, in a model of virus-induced asthma, IL-13producing NKT cells have a part in AHR development and lung injury. ${ }^{97}$

Through the development of a strong IL-4/IL-13 axis, NKT cells have a critical role in causing experimental allergic asthma, ${ }^{98-100}$ although this has been called into question. ${ }^{101}$ Airborne exposure to microbial products is clearly linked to asthma in humans ${ }^{102}$ and most aeroallergens are contaminated with microbial products (such as lipopolysaccharide) that can promote allergic airway inflammation in experimental systems. Whether naturally occurring substances present in the environment might serve as triggers of airway inflammation through direct NKT cell activation has been examined. Asthma reaction can be induced by respiratory coadministration of ovalbumin and bacterial lipids known to activate NKT cells or with $\alpha$-GalCer. ${ }^{13}$ It was also reported that house dust extracts contain lipid Ags that activate NKT cells independently of the TLR signaling pathway. ${ }^{103}$ Lipids from plants, and not only from microorganisms, might also contribute to asthma. For example, pollens contain phospholipids able to bind CD1d and activate human NKT cells. ${ }^{104}$ Thus, certain environmental factors, by indirectly (lipopolysaccharide) and/or directly (lipid Ags) activating NKT cells, might promote sensitization to conventional respiratory allergens.

In conclusion, NKT cells have a role in promoting allergic asthma by inducing AHR (in synergy or not with Th2 cells) and, through their adjuvant properties, by providing help to the development of pathogenic allergen-specific Th2 lymphocytes. Another mechanism has been proposed in which NKT cells are targeted by some Th2-associated factors to exacerbate asthma. Thus, NKT cells seem required for the deleterious effects of IL25 and thymic stromal lymphoprotein, two important factors produced by Th2 cells, mast cells, basophils, and/or epithelial cells and involved in asthma initiation and amplification. The Th2-promoting and asthma-triggered effects of IL-25 is due to CD4 ${ }^{+}$NKT cells expressing IL-17RB. ${ }^{31,32}$ In response to IL-25, this peculiar NKT cell subset produces IL-13 to amplify asthma reaction. Of note, NKT cells also produce IL-13 in response to thymic stromal lymphoprotein. ${ }^{105}$ Finally, IL-33 might also exacerbate asthma symptoms by promoting the release of Th2type cytokines by NKT cells. ${ }^{106,107}$ Attempts to harness NKT cell activities in asthma have been performed as treatment of ovalbumin-sensitized animals at the time of Ag challenge with $\alpha$-GalCer, ${ }^{108-111} \beta$-GlcCer (a naturally occurring lipid), ${ }^{112}$ or R848 (a TLR7 agonist) ${ }^{113}$, alleviated experimental asthma through IFN- $\gamma$ and/or IL-27 production. Prophylactic treatment of 2-week-old mice with some NKT cell agonists including a cholesterol-derived lipid from Helicobacter pylori can also protect against asthma, probably by inducing local expansion of a subset Th1-biased NKT cells. ${ }^{114}$

Of particular interest, interaction between endogenous flora and NKT cells during early life seems to be a cardinal factor to prevent uncontrolled inflammatory responses in adults such as asthma. ${ }^{10}$ Thus, mice bred under germ-free conditions show an accumulation of mucosal (Th2 bias) NKT cells via a CXCL16dependent mechanism. Interestingly, germ-free mice developed an allergic airway response significantly greater compared with specific pathogen-free mice, and this effect was CD1d dependent. $^{10}$

As NKT cell agonists are likely to be ubiquitous (soil, air, aqueous environment), ${ }^{103}$ it seems probable that repeated exposure to natural aerosols containing lipids might have significant pathological implications in humans. Although convergent studies demonstrate that NKT cells have a role in asthma in animal experimental models, the evidence in human subjects is still equivocal. ${ }^{115-117}$ An original study reported an abundance of NKT cells in the airways $\left(\sim 60 \%\right.$ of $\mathrm{CD} 4{ }^{+}$ T cells) of patients with asthma, ${ }^{118}$ but all other studies reported mild, if any, differences compared with controls. ${ }^{14,15,119-125}$

\section{Chronic obstructive pulmonary disease}

COPD is characterized by a chronic inflammation of the airways leading to airflow limitation. COPD has increased in frequency and severity in developed nations and now affects more than 200 million people (the fourth leading cause of death worldwide). ${ }^{126,127}$ Cigarette smoke and industrial pollutant exposure are the most important risks factors for COPD, and the imbalance between oxidants and antioxidants strongly contributes to the pathology. ${ }^{128}$ Patients developing COPD have an increased number of NKT cells in the lungs, ${ }^{97}$ although in a previous report no differences were found. ${ }^{15}$ Using an experimental model of chronic lung disease induced by Sendai virus infection, it was shown that NKT cells stimulate macrophages to produce IL-13, thus stimulating the development of goblet-cell metaplasia, AHR, and mucus production, independently from the adaptive immune response. ${ }^{97}$ More recently, using a model of chronic exposure to cigarette smoke mimicking COPD symptoms, we have demonstrated the requirement of NKT cells in altered lung functions and emphysema, a key feature of COPD (Pichavant et al., in press). In this setting, it is likely that oxidative stress induced by cigarette smoke initiates an activation pathway in sentinel cells resulting in the stimulation of NKT cells and thereafter lung dysfunctions. Thus, NKT cells might be involved in COPD, although further studies are clearly necessary to establish the relevance in the human system. 


\section{Acute lung injury and lung fibrosis}

NKT cells are detrimental in models of immune complex- and lipopolysaccharide-induced acute lung injury. ${ }^{129,130}$. In these settings, production of IFN- $\gamma$ by NKT cells enhances the local production of chemokines (MIP1 $\alpha /$ CCL3), thus amplifying the recruitment of inflammatory cells, such as granulocytes and/or monocytes, and promoting tissue damage. NKT cells are also deleterious during experimental sickle cell disease, a disease caused by mutation of $\beta$-globin and characterized by episodes of ischemia-reperfusion injury in the lungs. In this system, NKT cells promote chronic pulmonary inflammation and dysfunction through IFN- $\gamma$-induced recruitment of lymphocytes. ${ }^{131}$ In patients with sickle cell disease, NKT cells in blood are increased in absolute number and display an activated phenotype in comparison with healthy controls. ${ }^{131}$ Of interest, treatment of mice with an adenosine $2 \mathrm{~A}$ receptor agonist reverses pulmonary disease, in part, by inhibiting cytokine production by NKT cells. ${ }^{132}$ As some adenosine $2 \mathrm{~A}$ receptor agonist(s) are clinically approved in humans (e.g., to treat coronary disease), this might represent a general strategy to treat diseases associated with NKT cell activation.

As reviewed above, NKT cells are usually deleterious during lung inflammation. However, there are few examples suggesting that they can have a protective role. Pulmonary fibrosis is a progressive illness characterized by interstitial fibrosis. The potential role of NKT cells in acute pulmonary fibrosis has been studied using bleomycin. In this system, inflammatory cell infiltration and lung collagen deposition are the hallmarks of the pathology. Treatment with $\alpha$-GalCer attenuated the development of bleomycin-induced pulmonary fibrosis. ${ }^{133}$ Moreover, endogenous activation of NKT cells during bleomycin treatment also resulted in lower pathogenesis, although the mode of NKT cell activation in this system has not been characterized. Whatever the mechanisms, the antifibrotic role of NKT cells in pulmonary fibrosis was associated with IFN- $\gamma$ production and downregulation of TGF- $\beta 1$ synthesis. ${ }^{134,135}$ The potential role of NKT cells in chronic fibrosis is still unknown and no data exist to predict a role for NKT cells in human lung fibrosis. Finally, the production of IL- 4 by NKT cells protects against hypersensitivity pneumonitis by suppressing IFN- $\gamma$-producing neutrophils and $\mathrm{CD} 8^{+}$ T cells. ${ }^{136}$

\section{NKT CELLS DURING PULMONARY INFECTIONS}

A growing body of evidence documents a critical role for NKT cells in host defense against respiratory pathogens. On the other hand, they can inadvertently cause tissue damage associated with ongoing inflammation and, in some circumstances, control the runaway inflammation (Table 3 ).

\section{Viruses}

Pulmonary NKT cells contribute to pathogen clearance in acute viral infections, but this might be at the expense of uncontrolled inflammation ${ }^{50}$. This role in immune surveillance against viruses is partly based on their capacity to mature DCs and subsequently activate potent cytotoxic $\mathrm{NK}$ cells and $\mathrm{CD} 8^{+}$ $\mathrm{T}$ lymphocytes. For instance, endogenous or exogenous $(\alpha-$ GalCer) activation of lung NKT cells leads to antiviral $\mathrm{CD}^{+}$T-lymphocyte response and virus clearance during primary respiratory syncytial virus infection. ${ }^{137}$ Bronchiolitis is a feature of respiratory syncytial virus infection in young children. Through Th2-type cytokines, NKT cells might lead to pulmonary eosinophilia and fibrosis after respiratory syncytial virus infection, although this has not yet been studied in models of neonatal respiratory syncytial virus infection.

Influenza A virus (IAV) infection is one of the most important causes of respiratory tract diseases. ${ }^{138,139}$ Infection with IAV induces severe pulmonary immune pathology that leads to substantial human morbidity and mortality every winter. Further, IAV infection can enhance susceptibility to secondary bacterial infections, leading to increased lung pathogenesis and sepsis. ${ }^{140,141}$ In the mouse system, exogenous activation of the lung NKT cells by $\alpha$-GalCer protects against lethal $\mathrm{H} 1 \mathrm{~N} 1$ and $\mathrm{H} 3 \mathrm{~N} 2$ influenza in prophylactic settings (refs 142,143 and our unpublished data). When combined with inactivated viruses or IAV Ags, $\alpha$-GalCer exerts potent adjuvant properties to amplify antibody and $\mathrm{CD} 8{ }^{+}$T-lymphocyte responses able to neutralize IAV. ${ }^{19,142,144-148}$

The natural, endogenous, role of NKT cells has been examined during experimental influenza infection (Figure 2). There is a consensus that NKT deficiency resulted in worse inflammation, albeit through different mechanisms according to experimental conditions. ${ }^{143,149-151}$ Using a H1N1 strain, De Santo et al. ${ }^{149}$ suggested that the increased pathology observed in NKT-deficient animals was due to an enhanced virus spread. The authors proposed that NKT cells control IAV replication by blunting the immunosuppressive activity of myeloid-derived suppressive cells, a population that prevents specific $\mathrm{CD} 8{ }^{+} \mathrm{T}$-cell response. Using a highly inflammatory $\mathrm{H} 3 \mathrm{~N} 2$ strain, we have confirmed the role of NKT cells in CD8 ${ }^{+}$T-cell response, a phenomenon rather due to their ability to induce DC maturation/migration to the draining lymph nodes. ${ }^{151}$ Moreover, NKT cells regulate the strength of NK cell activation, ${ }^{151}$ a process that might be beneficial regarding the role of NK cells in IAV-associated pathogenesis. ${ }^{152,153}$ Kok et al. ${ }^{143}$ demonstrated that NKT cells control the recruitment of pulmonary inflammatory monocytes, a cell population that strongly contributes to IAVassociated pathogenesis. ${ }^{154}$ On the other hand, we proposed that the protective role of NKT cells on the control of pneumonia might be linked to their ability to produce IL-22. ${ }^{37}$ This cytokine protects airway epithelium against cell damage caused by $\mathrm{IAV}^{37}$ and, through this unique property, strengthens the epithelial barrier integrity to limit excessive lung inflammation. ${ }^{37,155-157}$ This later effect might be crucial to limit bacterial superinfection after influenza. ${ }^{155}$ Of interest, IAV infection of suckling mice leads to expansion of regulatory CD4 ${ }^{-}$NKT cells that protect against lung Th2-mediated damages. ${ }^{114}$ To conclude, NKT cells have multiple beneficial roles during experimental IAV infection, a property that is likely attributed to diverse NKT cell subsets. Whether or not 
Table 3 Role of type 1 NKT cells in pulmonary infections

\begin{tabular}{|c|c|c|c|c|c|c|c|}
\hline Pathology & Subset involved & $\begin{array}{l}\text { Cytokine } \\
\text { secretion }\end{array}$ & $\begin{array}{l}\text { Mechanisms } \\
\text { involved in NKT } \\
\text { cell activation }\end{array}$ & $\begin{array}{l}\text { Functions of NKT } \\
\text { cells }\end{array}$ & $\begin{array}{l}\text { Phenotype } \\
\text { in NKT cell- } \\
\text { deficient mice }\end{array}$ & $\begin{array}{l}\alpha \text {-GalCer (route } \\
\text { of administration) }\end{array}$ & Refs \\
\hline \multicolumn{8}{|l|}{ Viruses } \\
\hline RSV infection & Undetermined & $\mathrm{IFN}-\gamma$ & Not tested & $\begin{array}{l}\text { Promote specific } \\
\text { CD8 T-cell } \\
\text { response }\end{array}$ & $\begin{array}{l}\text { Increased illness } \\
\text { and impaired viral } \\
\text { clearance }\end{array}$ & $\begin{array}{l}\text { Delayed viral } \\
\text { clearance } \\
\text { (intraperitoneal) }\end{array}$ & 137 \\
\hline \multicolumn{8}{|l|}{ Influenza } \\
\hline $\mathrm{H} 1 \mathrm{~N} 1$ & Undetermined & Not tested & CD1d-dependent & $\begin{array}{l}\text { Promote IAV-specific } \\
\text { adaptive response and } \\
\text { control MDSC and } \\
\text { inflammatory mono- } \\
\text { cyte recruitment/ } \\
\text { activation }\end{array}$ & Increased mortality & $\begin{array}{l}\text { Protection } \\
\text { (intraperitoneal) } \\
\text { No protection } \\
\text { (intranasal) }\end{array}$ & $142,143,149$ \\
\hline H3N2 & $\begin{array}{l}\text { Various (including } \\
\text { NK1.1 } 1^{-} \text {NKT for } \\
\text { IL-22 production) }\end{array}$ & IFN- $\gamma / \mathrm{IL}-22$ & $\begin{array}{l}\text { IL-1 } \beta \text { and IL-23 } \\
\text { (through RIG-I and } \\
\text { TLR7 signaling) } \\
\text { concerning IL-22 } \\
\text { production }\end{array}$ & $\begin{array}{l}\text { Promote IAV-specific } \\
\text { CD8 }{ }^{+} \text {T-cell } \\
\text { response and } \\
\text { protect epithelial } \\
\text { barrier integrity }\end{array}$ & $\begin{array}{l}\text { Increased lung } \\
\text { inflammation and } \\
\text { mortality }\end{array}$ & $\begin{array}{l}\text { Protection } \\
\text { (intranasal) } \\
\text { No protection } \\
\text { (intravenous) }\end{array}$ & $\begin{array}{l}37,151 \text { and our } \\
\text { unpublished data }\end{array}$ \\
\hline $\mathrm{H} 3 \mathrm{~N} 1$ & $\mathrm{CD}^{-}{ }^{-} \mathrm{NKT}$ & IL-4/IL-13 & $\begin{array}{l}\text { T-bet and } \\
\text { TLR7-dependent }\end{array}$ & $\begin{array}{l}\text { Protect against } \\
\text { tissue damages }\end{array}$ & Not tested & Not tested & 114 \\
\hline \multicolumn{8}{|l|}{ Bacteria } \\
\hline $\begin{array}{l}\text { Streptococcus } \\
\text { pneumoniae }\end{array}$ & Various & $\begin{array}{l}\text { IFN- } \gamma \text { and } \\
\text { IL-17 }\end{array}$ & $\begin{array}{l}\text { CD1d- and IL-12- } \\
\text { dependent }\end{array}$ & $\begin{array}{l}\text { Neutrophilia and } \\
\text { bacterial clearance }\end{array}$ & $\begin{array}{l}\text { Increased } \\
\text { mortality }\end{array}$ & $\begin{array}{l}\text { Protection } \\
\text { (intraperitoneal, } \\
\text { intratracheal, } \\
\text { intranasal) }\end{array}$ & $52,60,159-161$ \\
\hline $\begin{array}{l}\text { Pseudomonas } \\
\text { aeruginosa }\end{array}$ & Undetermined & $\mathrm{IFN}-\gamma$ & Undetermined & $\begin{array}{l}\text { Neutrophilia and } \\
\text { enhance phagocytosis } \\
\text { by alveolar macro- } \\
\text { phages but called } \\
\text { into question }\end{array}$ & $\begin{array}{l}\text { Reduced bacterial } \\
\text { clearance but } \\
\text { called into } \\
\text { question }\end{array}$ & $\begin{array}{l}\text { Protection } \\
\text { (intraperitoneal) } \\
\text { but called into } \\
\text { question }\end{array}$ & 20,162 \\
\hline $\begin{array}{l}\text { Staphylo- } \\
\text { coccal entero- } \\
\text { toxin B }\end{array}$ & $\mathrm{V} \beta 8^{+} \mathrm{NKT}$ & Not tested & $\begin{array}{l}\text { Acts as a super Ag } \\
\text { (CD1d-independent } \\
\text { MHC 2-dependent) }\end{array}$ & $\begin{array}{l}\text { Vascular leak } \\
\text { and infiltration of } \\
\text { inflammatory cells }\end{array}$ & $\begin{array}{l}\text { Decreased } \\
\text { vascular leak } \\
\text { and inflammation }\end{array}$ & $\begin{array}{l}\text { Exacerbate lung } \\
\text { injury (intranasal) }\end{array}$ & $163-165$ \\
\hline $\begin{array}{l}\text { Chlamydia } \\
\text { pneumoniae }\end{array}$ & Undetermined & $\mathrm{IFN}-\gamma$ & Undetermined & $\begin{array}{l}\text { Promote specific } \\
\mathrm{CD}^{+}{ }^{+} \text {-cell } \\
\text { response }\end{array}$ & $\begin{array}{l}\text { Increased body } \\
\text { weight loss }\end{array}$ & $\begin{array}{l}\text { Protection } \\
\text { (intravenous) }\end{array}$ & 167 \\
\hline $\begin{array}{l}\text { Chlamydia } \\
\text { muridarum }\end{array}$ & Undetermined & $\mathrm{IL}-4$ & Undetermined & $\begin{array}{l}\text { Promote lung } \\
\text { infection by } \\
\text { positively influencing } \\
\text { Th2 response }\end{array}$ & Ameliorated & $\begin{array}{l}\text { Exacerbate chla- } \\
\text { mydial growth } \\
\text { (intravenous) }\end{array}$ & 166 \\
\hline $\begin{array}{l}\text { Legionella } \\
\text { pneumophilia }\end{array}$ & Undetermined & Not tested & Undetermined & Not tested & $\begin{array}{l}\text { More resistant } \\
\text { to infection }\end{array}$ & $\begin{array}{l}\text { No modulation in } \\
\text { disease para- } \\
\text { meters } \\
\text { (intraperitoneal) }\end{array}$ & 169 \\
\hline Mycobacteria & Undetermined & $\mathrm{IFN}-\gamma$ & $\begin{array}{l}\text { CD1d- and cytokine } \\
\text { dependent }\end{array}$ & Not tested & $\begin{array}{l}\text { Not critical for host } \\
\text { defense }\end{array}$ & $\begin{array}{l}\text { Protection } \\
\text { (intraperitoneal) }\end{array}$ & $170-177$ \\
\hline \multicolumn{8}{|l|}{ Fungi } \\
\hline $\begin{array}{l}\text { Cryptococcus } \\
\text { neoformans }\end{array}$ & Undetermined & $\mathrm{IFN}-\gamma$ & CCL2-dependent & $\begin{array}{l}\text { Required for Th1 } \\
\text { response } \\
\text { development }\end{array}$ & $\begin{array}{l}\text { Delay in fungal } \\
\text { clearance }\end{array}$ & $\begin{array}{l}\text { Alleviation of } \\
\text { C. neoformans } \\
\text { burden } \\
\text { (intraperitoneal) }\end{array}$ & 182,183 \\
\hline $\begin{array}{l}\text { Aspergillus } \\
\text { fumigatus }\end{array}$ & Undetermined & $\mathrm{IFN}-\gamma$ & $\begin{array}{l}\text { CD1d- and } \\
\text { IL-12-dependent } \\
\text { (MyD88- and } \\
\text { Dectin-1- } \\
\text { dependent) }\end{array}$ & Not tested & $\begin{array}{l}\text { Uncontrolled } \\
\text { growth of the } \\
\text { pathogen }\end{array}$ & Not tested & 184 \\
\hline
\end{tabular}

Abbreviations: $\alpha$-GalCer, $\alpha$-galactosylceramide; IFN, interferon; IAV, influenza A virus; IL, interleukin; MDSC, myeloid-derived suppressor cells; MHC, major histocompatibility complex; NKT, natural killer T cell; RIG-I, retinoic acid-inducible gene; RSV, respiratory syncitial virus; Th, T helper cell; TLR, toll-like receptor.

NKT cells have a role during human influenza and whether they have a different impact according to the pathogenicity index of IAV, await future studies.

\section{Bacteria and mycobacteria}

The extracellular, Gram-positive bacterium S. pneumoniae (also called pneumococcus) is a serious human pathogen that 


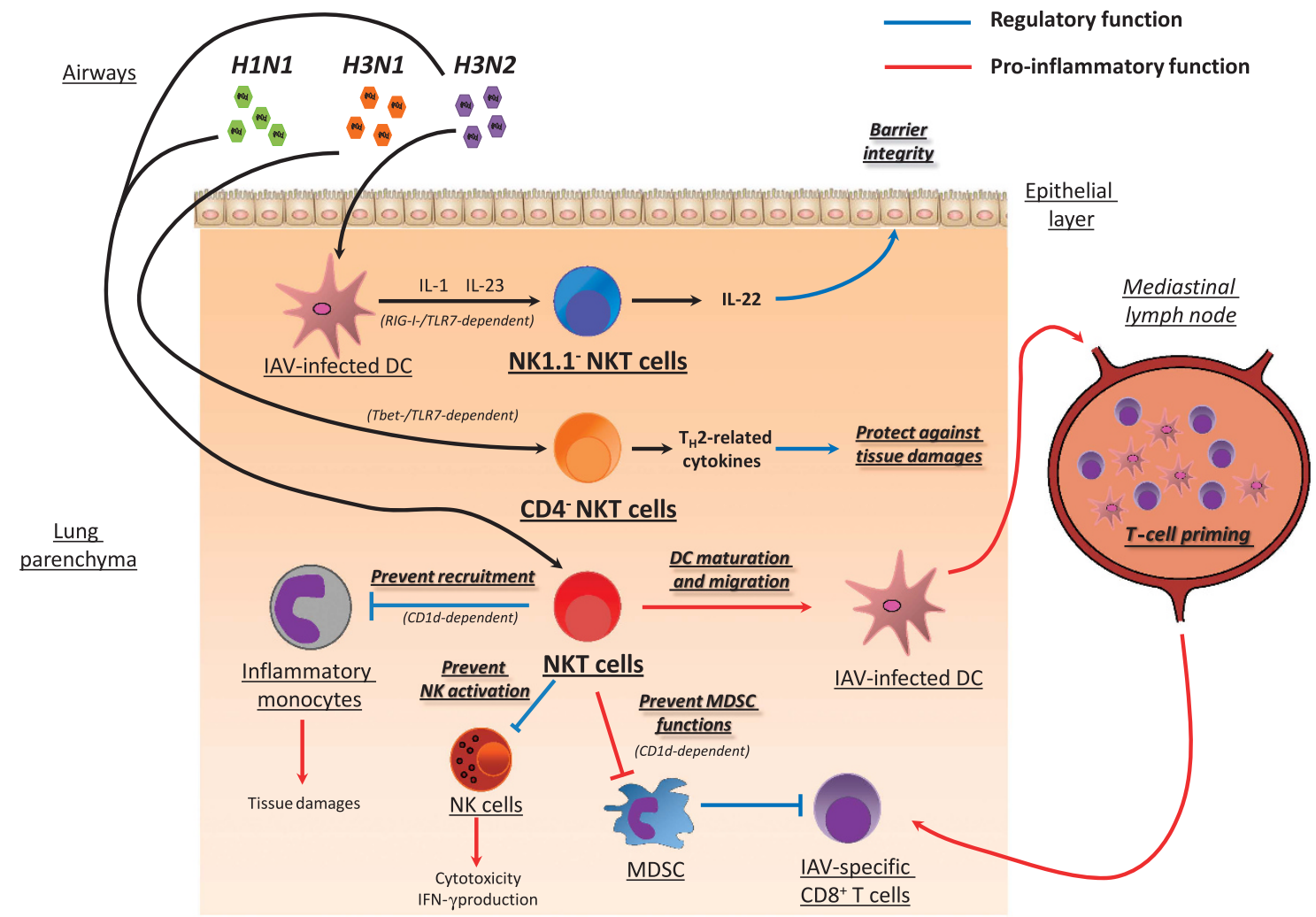

Figure 2 Versatile role of type 1 natural killer T (NKT) cells during experimental influenza A virus (IAV) infection.

causes severe lung and/or invasive disease. ${ }^{158}$ The natural positive role of NKT cells in the control of $S$. pneumoniae infection has been largely described, although the mechanisms involved are still elusive. ${ }^{52,60,159,160} \mathrm{We}$ and others have shown that intranasal administration of $\alpha$-GalCer can prophylactically protect against lethal S. pneumoniae infection. ${ }^{159-161}$ Analysis of mechanisms involved revealed that IFN- $\gamma$ and IL-17, as well as neutrophils, are necessary to clear $S$. pneumoniae. ${ }^{161}$ Although this is controversial, endogenous and exogenous activation of the lung NKT cells also lead to the control of Pseudomonas aeruginosa, a Gram-negative bacterium that causes major problems in immunocompromised individuals including patients with cystic fibrosis or other obstructive lung disorders. ${ }^{20,162}$ Staphylococcus aureus remains a common cause of nosocomial bacterial infections and are often antibiotic resistant. The natural role of NKT cells during pulmonary S. aureus infection is still unknown. However, it was reported that, after intranasal administration, Staphylococcal enterotoxin B acts as a super Ag to initiate NKT cell activation, which in turn triggers acute lung injury. ${ }^{163}$ However, when injected via the systemic route, NKT cells have a minor effect on super Ag-induced shock. ${ }^{164}$ Of interest, in both settings, NKT cell activation occurs in a CD1d-independent manner but through major histocompatibility complex class 2 /NKT TCR interaction. ${ }^{163-165}$ NKT cells have a protective or harmful role during infection with the intracellular bacteria Chlamydia, depending on the species studied. ${ }^{166,167}$ It is possible that the different organisms elicit activation of distinct subsets of NKT cells to promote either a protective Th1 response (C. pneumonia) or a detrimental Th2 response (C. muridarum) ${ }^{168}$ NKT cells might also be detrimental during Legionella pneumophila infection. ${ }^{169}$

The role of NKT cells during Mycobacterium infection has been extensively studied both in animal models and in humans. It is estimated that one-third of the world's population is infected with $M$. tuberculosis ( $\sim 2$ million deaths per year). There is evidence supporting the role of NKT cells in murine tuberculosis infection, although their absence is not essential to control the infection. ${ }^{170-174}$ By contrast, exogenous activation of NKT cells with $\alpha$-GalCer protected susceptible mice from tuberculosis. ${ }^{175}$ Moreover, early NKT cell activation has a role in resistance to $M$. bovis Bacillus Calmette-Guerin infection in mice presumably through an IFN- $\gamma$-dependent pathway. ${ }^{176,177}$ Of interest, NKT cell deficiency in humans might be crucial for the development of active/acute tuberculosis. These patients have less peripheral NKT cells compared with patients with latent tuberculosis, and normal NKT cell frequencies can be restored by treatment for active tuberculosis. ${ }^{39,178-181}$

\section{Fungi}

Fungi are widely distributed in nature causing human illnesses, including fatal invasive disease, especially in immune-compromised (e.g., acquired immunodeficiency syndrome, cancer) patients. Experimental models demonstrated that NKT cells have a positive role in the control of fungal infections including Cryptococcus neoformans, an opportunistic yeast-like fungus. ${ }^{182}$ NKT cells accumulate in the lungs in chemokine 
(C-C motif) ligand 2-dependent mechanism and control yeast burden by enhancing Th1 response. ${ }^{182}$ Further, $\alpha$-GalCer treatment alleviates $C$. neoformans burden locally (lungs) and systemically (spleen) by inducing a robust Th1 response, a phenomenon partially relying on cooperation with NK cells. ${ }^{183}$ The role of NKT cells in immunity against filamentous fungi (e.g., Aspergillus) has also been investigated. Interestingly, NKT control the early clearance of A. fumigatus and this is associated with rapid IFN- $\gamma$ release. ${ }^{184}$ Of interest, NKT cell activation requires $\beta-1,3$ glucans, which represent major fungal cell wall polysaccharides. The role of NKT cells during Candida (e.g., $C$. albicans) and Pneumocystis species pulmonary infections, which can also cause serious problems in immune-compromised individuals, is still ignored and worthy of future studies.

\section{CONCLUSIONS}

There has been significant progress in our knowledge about the modalities of activation and functions of NKT cells but many unanswered questions remain. As innate-driven NKT cell activation has a major influence on the strength and nature of immune responses, analysis of danger signals associated with sterile insults and infections must be further analyzed. This is important because according to the nature of the initial trigger, the way in which NKT cells are activated and influence the pathology might be different. What is the contribution of endogenous/exogenous lipid Ags vs. cytokines, or other host factors, on NKT cell activation and cytokine profiles? Research toward the identification of novel self-, microbial- (commensals and pathogens) and plant-derived Ags should be encouraged. The tissue where NKT cells are activated is also important and mucosal sites, including the lung, might offer a specific environment affecting the activation and functions of NKT cells.

There is also an urgent need to precisely define the NKT cell subset composition and functions at mucosal sites. Although NKT cells can modulate disease outcomes through the release of Th1-, Th2-, and Th17-related cytokines, it is also possible that regulatory NKT cells in the pulmonary mucosa have a crucial role, for instance, by controlling the production of harmful cytokines. A better characterization and knowledge of these regulatory cell subtypes will be an important breakthrough in the field.

As reviewed above, there is a consensus view about the significance of NKT cells in pulmonary disorders and respiratory infections in experimental models. The situation in humans is not so clear, as clinical information is sparse and contradictory data regarding the frequency and functions of NKT cells in patients have been reported. To establish a role for NKT cells in pulmonary diseases, and eventually the significance of NKT cells in prognosis and diagnosis, clinical studies are clearly warranted. It is expected that the use of more stringent criteria to analyze NKT cell subsets, larger cohorts, and a better definition of the clinical cases being analyzed will bring valuable information in the field.

Could NKT cells provide attractive therapeutic targets for treating acute or chronic inflammatory pathologies that affect the lungs and/or respiratory infections, and, if so, how can we progress toward the development of more effective treatments that target mucosal NKT cells? As mentioned above, an in-depth understanding of immune mechanisms that underlie NKT cell activation and functions is required in order to progress toward developing more effective treatments, for instance, in the design of drugs that block NKT cell functions and/or trafficking or that skew NKT cell functions. Among possible strategies, the use of pro-Th1, pro-Th2, or pro-Th17 NKT cell agonists as well as components that block NKT cell activation might be envisaged. Concerning the latter option, di-palmitoyl-phosphatidylethanolamine polyethylene glycol and GM3 represent interesting therapeutic candidates in NKT cell-mediated diseases as they bind to CD1d with high affinity without inducing NKT cell activation. ${ }^{100,185}$

There are many situations in which immune suppression arises and so NKT cell-based assistance of immunity to control respiratory infections might represent useful alternatives. Acute pulmonary viral infection such as influenza leads to secondary bacterial (e.g., S. pneumoniae) infection with dramatic clinical consequences. Chronic viral infections such as human immunodeficiency viruses or herpes viruses are associated with enhanced frequencies of respiratory infections (bacteria and fungi) as in some cancers. In these clinical situations, and in certain circumstances, the use of $\alpha$-GalCer or $\alpha$-GalCer derivatives might prevent respiratory infections.

Of importance, optimal NKT cell-based immunotherapy will not be reached without considering the diversified, and somehow opposing, functions of NKT cell subsets and, to a larger extent, of other CD1-restricted cells present in the lungs. In parallel to approaches based on classical experimental models, the use of humanized mice and nonhuman primates should be highly informative not only to better understand the role of NKT cells in pulmonary diseases but also for the design and application of preventive or curative NKT cell-based immunotherapies.

\section{ACKNOWLEDGMENTS}

We thank members of the laboratory, especially Dr C Faveeuw and colleagues from the field of NKT cell biology for helpful discussions. We apologize to colleagues whose works could not be cited because of space constraints. Drs Anne Tsicopoulos, Eric Viscogliosi (CIIL, Pasteur Institute, Lille) and Paul Beavis (Peter MacCallum Cancer Centre, Melbourne) are acknowledged for critical reading of this manuscript. CP is supported by the US Department of Defense (W81XWH-11-1-0585) and INSERM and FT by the CNRS.

\section{DISCLOSURE}

The authors declared no conflict of interest.

(c) 2013 Society for Mucosal Immunology

\section{REFERENCES}

1. Bendelac, A., Savage, P.B. \& Teyton, L. The biology of NKT cells. Annu. Rev. Immunol. 25, 297-336 (2007).

2. Cohen, N.R., Garg, S. \& Brenner, M.B. Antigen presentation by CD1 lipids, T cells, and NKT cells in microbial immunity. Adv. Immunol. 102, 1-94 (2009). 
3. Godfrey, D.I. \& Kronenberg, M. Going both ways: immune regulation via CD1d-dependent NKT cells. J. Clin. Invest. 114, 1379-1388 (2004).

4. Matsuda, J.L., Mallevaey, T., Scott-Browne, J. \& Gapin, L. CD1drestricted iNKT cells, the 'Swiss-Army knife' of the immune system. Curr. Opin. Immunol. 20, 358-368 (2008).

5. Rhost, S., Sedimbi, S., Kadri, N. \& Cardell, S.L. Immunomodulatory type II natural killer T lymphocytes in health and disease. Scand. J. Immunol. 76, 246-255 (2012).

6. Rossjohn, J., Pellicci, D.G., Patel, O., Gapin, L. \& Godfrey, D.I. Recognition of CD1d-restricted antigens by natural killer T cells. Nat. Rev. Immunol. 12, 845-857 (2012).

7. Berzofsky, J.A. \& Terabe, M. The contrasting roles of NKT cells in tumor immunity. Curr. Mol. Med. 9, 667-672 (2009).

8. Uldrich, A.P. et al. A semi-invariant Valpha10 + T cell antigen receptor defines a population of natural killer T cells with distinct glycolipid antigenrecognition properties. Nat. Immunol. 12, 616-623 (2011).

9. Godfrey, D.I., Stankovic, S. \& Baxter, A.G. Raising the NKT cell family. Nat. Immunol. 11, 197-206 (2010).

10. Olszak, T. et al. Microbial exposure during early life has persistent effects on natural killer T cell function. Science 336, 489-493 (2012).

11. Wingender, G. et al. Intestinal microbes affect phenotypes and functions of invariant natural killer T cells in mice. Gastroenterology 143, 418-428 (2012).

12. Lynch, L., O'Shea, D., Winter, D.C., Geoghegan, J., Doherty, D.G. \& O'Farrelly, C. Invariant NKT cells and CD1d $(+)$ cells amass in human omentum and are depleted in patients with cancer and obesity. Eur. J. Immunol. 39, 1893-1901 (2009).

13. Scanlon, S.T. et al. Airborne lipid antigens mobilize resident intravascular NKT cells to induce allergic airway inflammation. J. Exp. Med. 208 2113-2124 (2011).

14. Mutalithas, $\mathrm{K}$. et al. Bronchoalveolar lavage invariant natural killer T cells are not increased in asthma. J. Allergy Clin. Immunol. 119, 1274-1276 (2007).

15. Vijayanand, P. et al. Invariant natural killer T cells in asthma and chronic obstructive pulmonary disease. N. Engl. J. Med. 356, 1410-1422 (2007).

16. Kawano, T. et al. CD1d-restricted and TCR-mediated activation of valpha14 NKT cells by glycosylceramides. Science 278, 1626-1629 (1997).

17. Carnaud, $\mathrm{C}$ et al. Cutting edge: Cross-talk between cells of the innate immune system: NKT cells rapidly activate NK cells. J. Immunol. 163 4647-4650 (1999).

18. De Santo, C. et al. Invariant NKT cells modulate the suppressive activity of IL-10-secreting neutrophils differentiated with serum amyloid A. Nat. Immunol. 11, 1039-1046 (2010).

19. Galli, G. et al. Invariant NKT cells sustain specific B cell responses and memory. Proc. Natl Acad. Sci. USA 104, 3984-3989 (2007).

20. Nieuwenhuis, E.E. et al. CD1d-dependent macrophage-mediated clearance of Pseudomonas aeruginosa from lung. Nat. Med. 8 , 588-593 (2002).

21. Paget, C., Chow, M.T., Duret, H., Mattarollo, S.R. \& Smyth, M.J. Role of gammadelta $T$ cells in alpha-galactosylceramide-mediated immunity. J. Immunol. 188, 3928-3939 (2012).

22. Singh, N. et al. Cutting edge: activation of NK T cells by CD1d and alphagalactosylceramide directs conventional T cells to the acquisition of a Th2 phenotype. J. Immunol. 163, 2373-2377 (1999).

23. Wingender, G., Krebs, P., Beutler, B. \& Kronenberg, M. Antigen-specific cytotoxicity by invariant NKT cells in vivo is CD95/CD178-dependent and is correlated with antigenic potency. J. Immunol. 185, 2721-2729 (2010).

24. Hongo, D., Tang, X., Dutt, S., Nador, R.G. \& Strober, S. Interactions between NKT cells and Tregs are required for tolerance to combined bone marrow and organ transplants. Blood 119, 1581-1589 (2012).

25. Iwai, T. et al. Regulatory roles of NKT cells in the induction and maintenance of cyclophosphamide-induced tolerance. J. Immunol. 177, 8400-8409 (2006).

26. Roelofs-Haarhuis, K., Wu, X. \& Gleichmann, E. Oral tolerance to nickel requires CD4 + invariant NKT cells for the infectious spread of tolerance and the induction of specific regulatory T cells. J. Immunol. 173, 1043-1050 (2004)

27. Watte, C.M., Nakamura, T., Lau, C.H., Ortaldo, J.R. \& Stein-Streilein, J. Ly49 C/I-dependent NKT cell-derived IL-10 is required for corneal graft survival and peripheral tolerance. J. Leukoc. Biol. 83, 928-935 (2008).

28. Tupin, E., Kinjo, Y. \& Kronenberg, M. The unique role of natural killer Tcells in the response to microorganisms. Nat. Rev. Microbiol. 5, 405-417 (2007).

29. Crowe, N.Y. et al. Differential antitumor immunity mediated by NKT cell subsets in vivo. J. Exp. Med. 202, 1279-1288 (2005).

30. Gumperz, J.E., Miyake, S., Yamamura, T. \& Brenner, M.B. Functionally distinct subsets of CD1d-restricted natural killer T cells revealed by CD1d tetramer staining. J. Exp. Med. 195, 625-636 (2002).

31. Stock, P., Lombardi, V., Kohlrautz, V. \& Akbari, O. Induction of airway hyperreactivity by IL-25 is dependent on a subset of invariant NKT cells expressing IL-17RB. J. Immunol. 182, 5116-5122 (2009).

32. Terashima, A. et al. A novel subset of mouse NKT cells bearing the IL-17 receptor $\mathrm{B}$ responds to $\mathrm{IL}-25$ and contributes to airway hyperreactivity. J. Exp. Med. 205, 2727-2733 (2008).

33. Coquet, J.M. et al. Diverse cytokine production by NKT cell subsets and identification of an IL-17-producing CD4-NK1.1- NKT cell population. Proc. Natl Acad. Sci. USA 105, 11287-11292 (2008).

34. Michel, M.L. et al. Identification of an IL-17-producing NK1.1(neg) iNKT cell population involved in airway neutrophilia. J. Exp. Med. 204, 995-1001 (2007).

35. Doisne, J.M. et al. Skin and peripheral lymph node invariant NKT cells are mainly retinoic acid receptor-related orphan receptor (gamma)t + and respond preferentially under inflammatory conditions. J. Immunol. 183, 2142-2149 (2009).

36. Doisne, J.M. et al. Cutting edge: crucial role of IL-1 and IL-23 in the innate IL-17 response of peripheral lymph node NK1.1- invariant NKT cells to bacteria. J. Immunol. 186, 662-666 (2011).

37. Paget, C. et al. Interleukin-22 is produced by invariant natural killer $T$ lymphocytes during influenza A virus infection: potential role in protection against lung epithelial damages. J. Biol. Chem. 287, 8816-8829 (2012).

38. Dubin, P.J. \& Kolls, J.K. Th17 cytokines and mucosal immunity. Immunol. Rev. 226, 160-171 (2008).

39. Berzins, S.P., Smyth, M.J. \& Baxter, A.G. Presumed guilty: natural killer T cell defects and human disease. Nat. Rev. Immunol. 11, 131-142 (2011).

40. Karadimitris, A. \& Chaidos, A. The role of invariant NKT cells in allogeneic hematopoietic stem cell transplantation. Crit. Rev. Immunol. 32, 157-171 (2012).

41. Latour, S. Natural killer Tcells and X-linked lymphoproliferative syndrome. Curr. Opin. Allergy Clin. Immunol. 7, 510-514 (2007).

42. Wu, L. \& Van Kaer, L. Role of NKT cells in the digestive system. II. NKT cells and diabetes. Am. J. Physiol. Gastrointest. Liver Physiol. 293, G919-G922 (2007).

43. Motohashi, S., Okamoto, Y., Yoshino, I. \& Nakayama, T. Anti-tumor immune responses induced by iNKT cell-based immunotherapy for lung cancer and head and neck cancer. Clin. Immunol. 140, 167-176 (2011).

44. Schneiders, F.L. et al. Clinical experience with alpha-galactosylceramide (KRN7000) in patients with advanced cancer and chronic hepatitis B/C infection. Clin. Immunol. 140, 130-141 (2011).

45. Exley, M.A. \& Nakayama, T. NKT-cell-based immunotherapies in clinical trials. Clin. Immunol. 140, 117-118 (2011).

46. Metelitsa, L.S. Anti-tumor potential of type-I NKT cells against CD1d-positive and CD1d-negative tumors in humans. Clin. Immunol. 140, 119-129 (2011).

47. Cerundolo, V., Silk, J.D., Masri, S.H. \& Salio, M. Harnessing invariant NKT cells in vaccination strategies. Nat. Rev. Immunol. 9, 28-38 (2009).

48. Venkataswamy, M.M. et al. Incorporation of NKT cell-activating glycolipids enhances immunogenicity and vaccine efficacy of Mycobacterium bovis bacillus Calmette-Guerin. J. Immunol. 183, 1644-1656 (2009).

49. Faveeuw, C., Mallevaey, T. \& Trottein, F. Role of natural killer T lymphocytes during helminthic infection. Parasite 15, 384-388 (2008).

50. Tessmer, M.S., Fatima, A., Paget, C., Trottein, F. \& Brossay, L. NKT cell immune responses to viral infection. Expert Opin. Ther. Targets 13 153-162 (2009).

51. Scott-Browne, J.P. et al. Germline-encoded recognition of diverse glycolipids by natural killer T cells. Nat. Immunol. 8, 1105-1113 (2007).

52. Kinjo, $Y$. et al. Invariant natural killer $T$ cells recognize glycolipids from pathogenic Gram-positive bacteria. Nat. Immunol. 12, 966-974 (2011). 
53. Kinjo, Y. et al. Natural killer T cells recognize diacylglycerol antigens from pathogenic bacteria. Nat. Immunol. 7, 978-986 (2006).

54. Kinjo, Y. et al. Recognition of bacterial glycosphingolipids by natural killer $T$ cells. Nature 434, 520-525 (2005).

55. Mattner, J. et al. Exogenous and endogenous glycolipid antigens activate NKT cells during microbial infections. Nature 434, 525-529 (2005).

56. Sriram, V., Du, W., Gervay-Hague, J. \& Brutkiewicz, R.R. Cell wall glycosphingolipids of Sphingomonas paucimobilis are CD1d-specific ligands for NKT cells. Eur. J. Immunol. 35, 1692-1701 (2005).

57. Fischer, K. et al. Mycobacterial phosphatidylinositol mannoside is a natural antigen for CD1d-restricted Tcells. Proc. Nat/Acad. Sci. USA 101, 10685-10690 (2004).

58. Brigl, M. \& Brenner, M.B. How invariant natural killer T cells respond to infection by recognizing microbial or endogenous lipid antigens. Semin. Immunol. 22, 79-86 (2010).

59. Brigl, M., Bry, L., Kent, S.C., Gumperz, J.E. \& Brenner, M.B. Mechanism of CD1d-restricted natural killer Tcell activation during microbial infection. Nat. Immunol. 4, 1230-1237 (2003).

60. Brigl, M. et al. Innate and cytokine-driven signals, rather than microbial antigens, dominate in natural killer $\mathrm{T}$ cell activation during microbial infection. J. Exp. Med. 208, 1163-1177 (2011).

61. Darmoise, A. et al. Lysosomal alpha-galactosidase controls the generation of self lipid antigens for natural killer Tcells. Immunity 33, 216-228 (2010).

62. Paget, C. et al. Activation of invariant NKT cells by toll-like receptor 9-stimulated dendritic cells requires type I interferon and charged glycosphingolipids. Immunity 27, 597-609 (2007).

63. Salio, M. et al. Modulation of human natural killer T cell ligands on TLRmediated antigen-presenting cell activation. Proc. Natl Acad. Sci. USA 104, 20490-20495 (2007).

64. Paget, C. et al. Role of invariant NK T lymphocytes in immune responses to CpG oligodeoxynucleotides. J. Immunol. 182, 1846-1853 (2009).

65. Brennan, P.J. et al. Invariant natural killer Tcells recognize lipid self antigen induced by microbial danger signals. Nat. Immunol. 12, 1202-1211 (2011).

66. Pellicci, D.G. et al. Recognition of beta-linked self glycolipids mediated by natural killer T cell antigen receptors. Nat. Immunol. 12, 827-833 (2011).

67. Wu, D.Y., Segal, N.H., Sidobre, S., Kronenberg, M. \& Chapman, P.B. Cross-presentation of disialoganglioside GD3 to natural killer T cells. J. Exp. Med. 198, 173-181 (2003).

68. Fox, L.M. et al. Recognition of lyso-phospholipids by human natural killer T lymphocytes. PLoS Biol. 7, e1000228 (2009).

69. Venkataswamy, M.M. \& Porcelli, S.A. Lipid and glycolipid antigens of CD1d-restricted natural killer T cells. Semin. Immunol. 22, 68-78 (2010).

70. Zeissig, S. et al. Hepatitis B virus-induced lipid alterations contribute to natural killer $\mathrm{T}$ cell-dependent protective immunity. Nat. Med. 18, 1060-1068 (2012).

71. Ronet, C. et al. NKT cells are critical for the initiation of an inflammatory bowel response against Toxoplasma gondii. J. Immunol. 175, 899-908 (2005).

72. Bannai, M. et al. Abundance of unconventional CD8(+) natural killer T cells in the large intestine. Eur. J. Immunol. 31, 3361-3369 (2001).

73. Fuss, I.J. et al. Nonclassical CD1d-restricted NKTcells that produce IL-13 characterize an atypical Th2 response in ulcerative colitis. J. Clin. Invest. 113, 1490-1497 (2004).

74. liai, T., Watanabe, H., Suda, T., Okamoto, H., Abo, T. \& Hatakeyama, K. CD161 + T (NT) cells exist predominantly in human intestinal epithelium as well as in liver. Clin. Exp. Immunol. 129, 92-98 (2002).

75. O'Keeffe, J. et al. Diverse populations of T cells with NK cell receptors accumulate in the human intestine in health and in colorectal cancer. Eur. J. Immunol. 34, 2110-2119 (2004).

76. Kim, H.J., Hwang, S.J., Kim, B.K., Jung, K.C. \& Chung, D.H. NKT cells play critical roles in the induction of oral tolerance by inducing regulatory T cells producing $\mathrm{LL}-10$ and transforming growth factor beta, and by clonally deleting antigen-specific T cells. Immunology 118, 101-111 (2006).

77. Rajavelu, P., Rayapudi, M., Moffitt, M., Mishra, A. \& Mishra, A. Significance of para-esophageal lymph nodes in food or aeroallergen-induced iNKT cell-mediated experimental eosinophilic esophagitis. Am. J. Physiol. Gastrointest. Liver Physiol. 302, G645-G654 (2012).
78. Jyonouchi, S. et al. Invariant natural killer Tcells from children with versus without food allergy exhibit differential responsiveness to milk-derived sphingomyelin. J. Allergy Clin. Immunol. 128, 102-109 e113 (2011).

79. Ulanova, M. et al. Expression of CD1d in the duodenum of patients with cow's milk hypersensitivity. Scand. J. Immunol. 52, 609-617 (2000).

80. Wingender, G. \& Kronenberg, M. Role of NKT cells in the digestive system. IV. The role of canonical natural killer T cells in mucosal immunity and inflammation. Am. J. Physiol. Gastrointest. Liver Physiol. 294, G1-G8 (2008).

81. Zeissig, S., Kaser, A., Dougan, S.K., Nieuwenhuis, E.E. \& Blumberg, R.S. Role of NKT cells in the digestive system. III. Role of NKT cells in intestinal immunity. Am. J. Physiol. Gastrointest. Liver Physiol. 293, G1101-G1105 (2007).

82. Arrunategui-Correa, V. \& Kim, H.S. The role of CD1d in the immune response against Listeria infection. Cell Immunol. 227, 109-120 (2004).

83. Emoto, M., Yoshizawa, I., Emoto, Y., Miamoto, M., Hurwitz, R. \& Kaufmann, S.H. Rapid development of a gamma interferon-secreting glycolipid/CD1d-specific Valpha14 + NK1.1-T-cell subset after bacterial infection. Infect. Immun. 74, 5903-5913 (2006).

84. Ranson, $T$. et al. Invariant $V$ alpha $14+$ NKT cells participate in the early response to enteric Listeria monocytogenes infection. J. Immunol. 175, 1137-1144 (2005).

85. Smiley, S.T. et al. Exacerbated susceptibility to infection-stimulated immunopathology in CD1d-deficient mice. J. Immunol. 174, 7904-7911 (2005).

86. Wilson, M.T. et al. The response of natural killer T cells to glycolipid antigens is characterized by surface receptor down-modulation and expansion. Proc. Natl Acad. Sci. USA 100, 10913-10918 (2003).

87. Ashkar, A.A. \& Rosenthal, K.L. Interleukin-15 and natural killer and NKT cells play a critical role in innate protection against genital herpes simplex virus type 2 infection. J. Virol. 77, 10168-10171 (2003).

88. Jiang, J. et al. Interruption of CXCL13-CXCR5 axis increases upper genital tract pathology and activation of NKT cells following chlamydial genital infection. PloS ONE 7, e47487 (2012).

89. Wang, $\mathrm{H}$. et al. Protective role of alpha-galactosylceramide-stimulated natural killer T cells in genital tract infection with Chlamydia muridarum. FEMS Immunol. Med. Microbiol. 65, 43-54 (2012).

90. Holtzman, M.J. Asthma as a chronic disease of the innate and adaptive immune systems responding to viruses and allergens. J. Clin. Invest. 122, 2741-2748 (2012).

91. Holgate, S.T. Innate and adaptive immune responses in asthma. Nat. Med. 18, 673-683 (2012).

92. Chuang, Y.H., Wang, T.C., Jen, H.Y., Yu, A.L. \& Chiang, B.L. alphaGalactosylceramide-induced airway eosinophilia is mediated through the activation of NKT cells. J. Immunol. 186, 4687-4692 (2011).

93. Matangkasombut, P. et al. Natural killer T cells in the lungs of patients with asthma. J. Allergy Clin. Immunol. 123, 1181-1185 (2009).

94. Meyer, E.H. et al. Glycolipid activation of invariant T cell receptor + NK T cells is sufficient to induce airway hyperreactivity independent of conventional CD4+ T cells. Proc. Natl Acad. Sci. USA 103, 2782-2787 (2006).

95. Renukaradhya, G.J. et al. Functional invariant NKT cells in pig lungs regulate the airway hyperreactivity: a potential animal model. J. Clin. Immunol. 31, 228-239 (2011).

96. Pichavant, M. et al. Ozone exposure in a mouse model induces airway hyperreactivity that requires the presence of natural killer Tcells and IL-17. J. Exp. Med. 205, 385-393 (2008).

97. Kim, E.Y. et al. Persistent activation of an innate immune response translates respiratory viral infection into chronic lung disease. Nat. Med. 14, 633-640 (2008)

98. Akbari, O. et al. Essential role of NKT cells producing IL-4 and IL-13 in the development of allergen-induced airway hyperreactivity. Nat. Med. 9 , 582-588 (2003)

99. Lisbonne, M. et al. Cutting edge: invariant $V$ alpha 14 NKT cells are required for allergen-induced airway inflammation and hyperreactivity in an experimental asthma model. J. Immunol. 171, 1637-1641 (2003).

100. Lombardi, V. et al. A CD1d-dependent antagonist inhibits the activation of invariant NKT cells and prevents development of allergen-induced airway hyperreactivity. J. Immunol. 184, 2107-2115 (2010). 
101. Das, J. et al. Natural killer T cells and CD8 + T cells are dispensable for $T$ cell-dependent allergic airway inflammation. Nat. Med. 12, 1345-1346 (2006). author reply 1347.

102. Williams, L.K., Ownby, D.R., Maliarik, M.J. \& Johnson, C.C. The role of endotoxin and its receptors in allergic disease. Ann. Allergy Asthma Immunol. 94, 323-332 (2005).

103. Wingender, G. et al. Invariant NKT cells are required for airway inflammation induced by environmental antigens. J. Exp. Med. 208, 1151-1162 (2011).

104. Agea, E. et al. Human CD1-restricted T cell recognition of lipids from pollens. J. Exp. Med. 202, 295-308 (2005).

105. Nagata, Y., Kamijuku, H., Taniguchi, M., Ziegler, S. \& Seino, K. Differential role of thymic stromal lymphopoietin in the induction of airway hyperreactivity and Th2 immune response in antigen-induced asthma with respect to natural killer Tcell function. Int. Arch. Allergy Immunol. 144, 305-314 (2007).

106. Bourgeois, E. et al. The pro-Th2 cytokine IL-33 directly interacts with invariant NKT and NK cells to induce IFN-gamma production. Eur. J. Immunol. 39, 1046-1055 (2009).

107. Smithgall, M.D., Comeau, M.R., Yoon, B.R., Kaufman, D., Armitage, R. \& Smith, D.E. IL-33 amplifies both Th1- and Th2-type responses through its activity on human basophils, allergen-reactive Th2 cells, iNKT and NK cells. Int. Immunol. 20, 1019-1030 (2008).

108. Fujita, H. et al. Production of both IL-27 and IFN-gamma after the treatment with a ligand for invariant NK T cells is responsible for the suppression of Th2 response and allergic inflammation in a mouse experimental asthma model. J. Immunol. 183, 254-260 (2009).

109. Hachem, P. et al. Alpha-galactosylceramide-induced iNKT cells suppress experimental allergic asthma in sensitized mice: role of IFN-gamma. Eur. J. Immunol. 35, 2793-2802 (2005).

110. Matsuda, H. et al. alpha-Galactosylceramide, a ligand of natural killer $T$ cells, inhibits allergic airway inflammation. Am. J. Respir. Cell Mol. Biol. 33, 22-31 (2005).

111. Morishima, Y. et al. Suppression of eosinophilic airway inflammation by treatment with alpha-galactosylceramide. Eur. J. Immunol. 35, 2803-2814 (2005).

112. Horani, A. et al. Immune modulation of ovalbumin-induced lung injury in mice using beta-glucosylceramide and a potential role of the liver. Immunobiology 216, 548-557 (2011).

113. Grela, F. et al. The TLR7 agonist R848 alleviates allergic inflammation by targeting invariant NKT cells to produce IFN-gamma. J. Immunol. 186, 284-290 (2011).

114. Chang, Y.J. et al. Influenza infection in suckling mice expands an NKT cell subset that protects against airway hyperreactivity. J. Clin. Invest. 121, 57-69 (2011)

115. Iwamura, C. \& Nakayama, T. Role of NKT cells in allergic asthma. Curr. Opin. Immunol. 22, 807-813 (2010).

116. Thomas, S.Y., Chyung, Y.H. \& Luster, A.D. Natural killer T cells are not the predominant $\mathrm{T}$ cell in asthma and likely modulate, not cause, asthma. J. Allergy Clin. Immunol. 125, 980-984 (2010).

117. Umetsu, D.T. \& Dekruyff, R.H. Natural killer T cells are important in the pathogenesis of asthma: the many pathways to asthma. J. Allergy Clin. Immunol. 125, 975-979 (2010).

118. Akbari, O. et al. CD4 + invariant T-cell-receptor + natural killer T cells in bronchial asthma. N. Engl. J. Med. 354, 1117-1129 (2006).

119. Brooks, C.R., Weinkove, R., Hermans, I.F., van Dalen, C.J. \& Douwes, J. Invariant natural killer T cells and asthma: immunologic reality or methodologic artifact? J. Allergy Clin. Immunol. 126, 882-885 (2010).

120. Hamzaoui, A. et al. NKT cells in the induced sputum of severe asthmatics. Mediators Inflamm. 2006, 71214 (2006).

121. Koh, Y.I. et al. Natural killer T cells are dispensable in the development of allergen-induced airway hyperresponsiveness, inflammation and remodelling in a mouse model of chronic asthma. Clin. Exp. Immunol. 161, 159-170 (2010).

122. Matangkasombut, P. et al. Direct activation of natural killer Tcells induces airway hyperreactivity in nonhuman primates. J. Allergy Clin. Immunol. 121, 1287-1289 (2008).

123. Pham-Thi, N., de Blic, J., Le Bourgeois, M., Dy, M., Scheinmann, P. \& Leite-de-Moraes, M.C. Enhanced frequency of immunoregulatory invariant natural killer T cells in the airways of children with asthma. J. Allergy Clin. Immunol. 117, 217-218 (2006).

124. Reynolds, C. et al. Natural killer T cells in bronchial biopsies from human allergen challenge model of allergic asthma. J. Allergy Clin. Immunol. 124, 860-862 (2009). author reply 862.

125. Thomas, S.Y., Lilly, C.M. \& Luster, A.D. Invariant natural killer T cells in bronchial asthma. N. Engl. J. Med. 354, 2613-2616. author reply 2613-2616 (2006).

126. Barnes, P.J. Chronic obstructive pulmonary disease. N. Engl. J. Med. 343, 269-280 (2000).

127. Lopez, A.D. et al. Chronic obstructive pulmonary disease: current burden and future projections. Eur. Respir. J. 27, 397-412 (2006).

128. Mannino, D.M. \& Buist, A.S. Global burden of COPD: risk factors, prevalence, and future trends. Lancet 370, 765-773 (2007).

129. Aoyagi, T. et al. Activation of pulmonary invariant NKT cells leads to exacerbation of acute lung injury caused by LPS through local production of IFN-gamma and TNF-alpha by Gr-1 + monocytes. Int. Immunol. 23, 97-108 (2011).

130. Kim, J.H. \& Chung, D.H. CD1d-restricted IFN-gamma-secreting NKT cells promote immune complex-induced acute lung injury by regulating macrophage-inflammatory protein-1alpha production and activation of macrophages and dendritic cells. J. Immunol. 186, 1432-1441 (2011)

131. Wallace, K.L. et al. NKT cells mediate pulmonary inflammation and dysfunction in murine sickle cell disease through production of IFNgamma and CXCR3 chemokines. Blood 114, 667-676 (2009).

132. Wallace, K.L. \& Linden, J. Adenosine A2A receptors induced on iNKT and NK cells reduce pulmonary inflammation and injury in mice with sickle cell disease. Blood 116, 5010-5020 (2010).

133. Kimura, T. et al. Treatment with alpha-galactosylceramide attenuates the development of bleomycin-induced pulmonary fibrosis. J. Immunol. 172, 5782-5789 (2004).

134. Horikawa, M. et al. E- and P-selectins synergistically inhibit bleomycininduced pulmonary fibrosis. Am. J. Pathol. 169, 740-749 (2006).

135. Kim, J.H., Kim, H.Y., Kim, S., Chung, J.H., Park, W.S. \& Chung, D.H. Natural killer T (NKT) cells attenuate bleomycin-induced pulmonary fibrosis by producing interferon-gamma. Am. J. Pathol. 167, 1231-1241 (2005).

136. Hwang, S.J., Kim, S., Park, W.S. \& Chung, D.H. IL-4-secreting NKT cells prevent hypersensitivity pneumonitis by suppressing IFN-gamma-producing neutrophils. J. Immunol. 177, 5258-5268 (2006).

137. Johnson, T.R., Hong, S., Van Kaer, L., Koezuka, Y. \& Graham, B.S. NKT cells contribute to expansion of CD8(+) T cells and amplification of antiviral immune responses to respiratory syncytial virus. J. Virol. 76, 4294-4303 (2002).

138. Monto, A.S. Epidemiology of influenza. Vaccine 26 (Suppl 4), D45-D48 (2008).

139. Palese, P. Influenza: old and new threats. Nat. Med. 10 (12 Suppl), S82-S87 (2004).

140. Hartshorn, K. L. New look at an old problem: bacterial superinfection after influenza. Am. J. Pathol. 176, 536-539 (2010).

141. Morens, D.M., Taubenberger, J.K. \& Fauci, A.S. Predominant role of bacterial pneumonia as a cause of death in pandemic influenza: implications for pandemic influenza preparedness. J. Infect. Dis. 198, 962-970 (2008).

142. Ho, L.P., Denney, L., Luhn, K., Teoh, D., Clelland, C. \& McMichael, A.J. Activation of invariant NKT cells enhances the innate immune response and improves the disease course in influenza A virus infection. Eur. J. Immunol. 38, 1913-1922 (2008).

143. Kok, W.L. et al. Pivotal Advance: Invariant NKT cells reduce accumulation of inflammatory monocytes in the lungs and decrease immune-pathology during severe influenza A virus infection. J. Leukoc. Biol. 91, 357-368 (2012).

144. Guillonneau, C. et al. Combined NKT cell activation and influenza virus vaccination boosts memory CTL generation and protective immunity. Proc. Natl Acad. Sci. USA 106, 3330-3335 (2009).

145. Kamijuku, $H$. et al. Mechanism of NKT cell activation by intranasal coadministration of alpha-galactosylceramide, which can induce cross-protection against influenza viruses. Mucosal Immunol. 1, 208-218 (2008). 
146. Kopecky-Bromberg, S.A. et al. Alpha-C-galactosylceramide as an adjuvant for a live attenuated influenza virus vaccine. Vaccine $\mathbf{2 7}$, 3766-3774 (2009).

147. Li, K., Luo, J., Wang, C. \& He, H. alpha-Galactosylceramide potently augments $\mathrm{M} 2 \mathrm{e}$-induced protective immunity against highly pathogenic H5N1 avian influenza virus infection in mice. Vaccine 29, 7711-7717 (2011).

148. Youn, H.J. et al. A single intranasal immunization with inactivated influenza virus and alpha-galactosylceramide induces long-term protective immunity without redirecting antigen to the central nervous system. Vaccine 25, 5189-5198 (2007).

149. De Santo, C. et al. Invariant NKT cells reduce the immunosuppressive activity of influenza A virus-induced myeloid-derived suppressor cells in mice and humans. J. Clin. Invest. 118, 4036-4048 (2008).

150. Maazi, H. et al. Lack of PD-L1 expression by iNKT cells improves the course of influenza A infection. PloS ONE 8, e59599 (2013).

151. Paget, C. et al. Potential role of invariant NKT cells in the control of pulmonary inflammation and CD8 $+\mathrm{T}$ cell response during acute influenza A virus H3N2 pneumonia. J. Immunol. 186, 5590-5602 (2011).

152. Abdul-Careem, M.F. et al. Critical role of natural killer cells in lung immunopathology during influenza infection in mice. J. Infect. Dis. 206, 167-177 (2012).

153. Zhou, G., Juang, S.W. \& Kane, K.P. NK cells exacerbate the pathology of influenza virus infection in mice. Eur. J. Immunol. 43, 929-938 (2013).

154. Aldridge, J.R. Jr et al. TNF/iNOS-producing dendritic cells are the necessary evil of lethal influenza virus infection. Proc. Natl Acad. Sci. USA 106, 5306-5311 (2009).

155. Ivanov, S. et al. Interleukin-22 reduces lung inflammation during influenza $A$ virus infection and protects against secondary bacterial infection. J. Virol. 87, 6911-6924 (2013).

156. Kumar, P., Thakar, M.S., Ouyang, W. \& Malarkannan, S. IL-22 from conventional NK cells is epithelial regenerative and inflammation protective during influenza infection. Mucosal Immunol. 6, 69-82 (2013).

157. Pociask, D.A. et al. IL-22 is essential for lung epithelial repair following influenza infection. Am. J. Pathol. 182, 1286-1296 (2013).

158. van der Poll, T. \& Opal, S.M. Pathogenesis, treatment, and prevention of pneumococcal pneumonia. Lancet 374, 1543-1556 (2009).

159. Kawakami, K. et al. Critical role of Valpha14 + natural killer T cells in the innate phase of host protection against Streptococcus pneumoniae infection. Eur. J. Immunol. 33, 3322-3330 (2003).

160. Nakamatsu, M. et al. Role of interferon-gamma in Valpha14 + natural killer T cell-mediated host defense against Streptococcus pneumoniae infection in murine lungs. Microbes Infect. 9, 364-374 (2007).

161. Ivanov, S. et al. Key role for respiratory CD103(+) dendritic cells, IFNgamma, and IL-17 in protection against Streptococcus pneumoniae infection in response to alpha-galactosylceramide. J Infect. Dis. 206, 723-734 (2012).

162. Kinjo, T. et al. NKT cells play a limited role in the neutrophilic inflammatory responses and host defense to pulmonary infection with Pseudomonas aeruginosa. Microbes Infect. 8, 2679-2685 (2006).

163. Rieder, S.A., Nagarkatti, P. \& Nagarkatti, M. CD1d-independent activation of invariant natural killer T cells by Staphylococcal enterotoxin B through major histocompatibility complex class $\| / T$ cell receptor interaction results in acute lung injury. Infect. Immun. 79, 3141-3148 (2011).

164. Ragin, M.J., Sahu, N. \& August, A. Differential regulation of cytokine production by CD1d-restricted NKT cells in response to superantigen staphylococcal enterotoxin B exposure. Infect. Immun. 74, 282-288 (2006).

165. Hayworth, J.L., Mazzuca, D.M., Maleki Vareki, S., Welch, I., McCormick, J.K. \& Haeryfar, S.M. CD1d-independent activation of mouse and human iNKT cells by bacterial superantigens. Immunol. Cell Biol. 90, 699-709 (2012).
166. Bilenki, L., Wang, S., Yang, J., Fan, Y., Joyee, A.G. \& Yang, X. NK T cell activation promotes Chlamydia trachomatis infection in vivo. J. Immunol. 175, 3197-3206 (2005).

167. Joyee, A.G., Qiu, H., Wang, S., Fan, Y., Bilenki, L. \& Yang, X. Distinct NKT cell subsets are induced by different Chlamydia species leading to differential adaptive immunity and host resistance to the infections. J. Immunol. 178, 1048-1058 (2007).

168. Yang, X. Natural killer T (NKT) cell subsets in chlamydial infections. Adv. Exp. Med. Biol. 601, 243-246 (2007).

169. Hayakawa, K. et al. Paradoxically high resistance of natural killer T (NKT) cell-deficient mice to Legionella pneumophila: another aspect of NKT cells for modulation of host responses. J. Med. Microbiol. 57 (Pt 11), 1340-1348 (2008).

170. Behar, S.M., Dascher, C.C., Grusby, M.J., Wang, C.R. \& Brenner, M.B. Susceptibility of mice deficient in CD1D or TAP1 to infection with Mycobacterium tuberculosis. J. Exp. Med. 189, 1973-1980 (1999).

171. Sada-Ovalle, I., Chiba, A., Gonzales, A., Brenner, M.B. \& Behar, S.M. Innate invariant NKT cells recognize Mycobacterium tuberculosisinfected macrophages, produce interferon-gamma, and kill intracellular bacteria. PLoS Pathogens 4, e1000239 (2008).

172. Skold, M. \& Behar, S.M. Role of CD1d-restricted NKT cells in microbial immunity. Infect. Immun. 71, 5447-5455 (2003).

173. Sousa, A.O. et al. Relative contributions of distinct MHC class I-dependent cell populations in protection to tuberculosis infection in mice. Proc. Natl Acad. Sci. USA 97, 4204-4208 (2000).

174. Szalay, G., Zugel, U., Ladel, C.H. \& Kaufmann, S.H. Participation of group $2 \mathrm{CD} 1$ molecules in the control of murine tuberculosis. Microbes Infect. 1, 1153-1157 (1999).

175. Chackerian, A., Alt, J., Perera, V. \& Behar, S.M. Activation of NKT cells protects mice from tuberculosis. Infect. Immun. 70, 6302-6309 (2002).

176. Chiba, A., Dascher, C.C., Besra, G.S. \& Brenner, M.B. Rapid NKT cell responses are self-terminating during the course of microbial infection. J. Immunol. 181, 2292-2302 (2008).

177. Dieli, F. et al. An anti-inflammatory role for $V$ alpha 14 NK T cells in Mycobacterium bovis bacillus Calmette-Guerin-infected mice. J. Immunol. 171, 1961-1968 (2003).

178. Im, J.S. et al. Alteration of the relative levels of iNKT cell subsets is associated with chronic mycobacterial infections. Clin. Immunol. 127, 214-224 (2008).

179. Montoya, C.J., Catano, J.C., Ramirez, Z., Rugeles, M.T., Wilson, S.B. \& Landay, A.L. Invariant NKT cells from HIV-1 or Mycobacterium tuberculosis-infected patients express an activated phenotype. Clin. Immunol. 127, 1-6 (2008).

180. Sutherland, J.S. et al. High granulocyte/lymphocyte ratio and paucity of NKT cells defines TB disease in a TB-endemic setting. Tuberculosis 89 , 398-404 (2009).

181. Veenstra, H. et al. Changes in leucocyte and lymphocyte subsets during tuberculosis treatment; prominence of CD3dimCD56 + natural killer T cells in fast treatment responders. Clin. Exp. Immunol. 145, 252-260 (2006).

182. Kawakami, K. et al. Monocyte chemoattractant protein-1-dependent increase of $\mathrm{V}$ alpha $14 \mathrm{NKT}$ cells in lungs and their roles in Th1 response and host defense in cryptococcal infection. J. Immunol. 167, 6525-6532 (2001).

183. Kawakami, K. et al. Activation of Valpha14(+) natural killer T cells by alpha-galactosylceramide results in development of Th1 response and local host resistance in mice infected with Cryptococcus neoformans. Infect. Immun. 69, 213-220 (2001).

184. Cohen, N.R. et al. Innate recognition of cell wall beta-glucans drives invariant natural killer Tcell responses against fungi. Cell Host Microbe 10, 437-450 (2011).

185. Park, J.E. et al. Fine specificity of natural killer T cells against GD3 ganglioside and identification of GM3 as an inhibitory natural killer T-cell ligand. Immunology 123, 145-155 (2008). 